\title{
Peas Can Replace Soybean Meal and Corn Grain in Dairy Cow Diets
}

\author{
M. Vander Pol, A. N. Hristov, ${ }^{1}$ S. Zaman, and N. Delano \\ Department of Animal and Veterinary Science, University of Idaho, Moscow 83844
}

\begin{abstract}
The objective of this experiment was to investigate the effect of a partial substitution of soybean meal and corn grain with field peas in dairy cow diets on intake, milk yield and composition, nutrient digestibility, and urinary and fecal $\mathrm{N}$ losses. Twenty-four lactating Holstein cows were blocked into 2 groups based on parity, days in milk, and milk yield at the end of a 2 -wk covariate period. Cows within group were randomly assigned to 1 of 2 treatments: control and pea diets. Approximately $45 \%$ of the corn grain and $78 \%$ of the soybean meal in the control diet were replaced with 15\% (dry matter basis) field peas in the experimental diet. The peas used in the trial contained $25 \%$ crude protein and an estimated $1.98 \mathrm{Mcal}$ of net energy for lactation/kg. The experiment continued for $70 \mathrm{~d}$. Dry matter intake (25.9 and $26.3 \mathrm{~kg} / \mathrm{d}$; control and pea diets, respectively), milk yield (35.4 and $35.6 \mathrm{~kg} / \mathrm{d}$ ), $4 \%$ fat-corrected milk yield (33.0 and $34.6 \mathrm{~kg} / \mathrm{d})$, milk fat (3.54 and $3.76 \%$ ) and protein (3.00 and $2.99 \%)$ content and yields, and milk $\mathrm{N}$ efficiency (26 and 24\%) were not affected by diet. Concentration of milk urea nitrogen was also not affected by treatment $(14.3$ and $15.0 \mathrm{mg} / \mathrm{dL}$, respectively). Intake of organic matter and $\mathrm{N}$ were not affected by diet, but intake of neutral detergent fiber was lower and that of starch greater with the control diet. Total tract apparent digestibility of starch was lower (92.1 vs. $88.3 \%$, respectively) and that of dry matter and organic matter tended to be lower with the pea compared with the control diet. Urinary and fecal $\mathrm{N}$ losses were not different between the 2 diets. Panel evaluation of milk from the 2 diets indicated no differences in the organoleptic characteristics of milk. This experiment demonstrated that field peas could be safely fed to high-producing dairy cows at a $15 \%$ inclusion rate, replacing soybean meal and corn grain. At this inclusion rate, no effects on milk yield or milk composition were observed.
\end{abstract} Key words: field pea, dairy cow, milk production

Received July 24, 2007.

Accepted October 5, 2007.

${ }^{1}$ Corresponding author: ahristov@uidaho.edu

\section{INTRODUCTION}

The growing dairy industry in the Pacific Northwest, and particularly Idaho, offers an opportunity for expanding the markets for nontraditional, locally grown feedstuffs such as field peas. Field peas (or dry peas, split peas; Pisum sativum) have relatively high CP content and contain a significant amount of energy in the form of starch (NRC, 1998; Beyer et al., 2003), which makes them a unique feed that can be substituted for higher-priced protein and energy commodities like soybean meal (SBM), corn, and barley in dairy cow diets. In addition, leguminous seeds are rich in phenolic compounds (Duenãs et al., 2004), which have strong antioxidant activities and may contribute to milk flavor and enhance the healthful characteristics of milk (Besle et al., 2005; Moon et al., 2006). As are all legumes, peas are an excellent rotational crop in cereal production systems. Relevant research, cost, and availability are the key factors that will determine the feasibility of feeding this nontraditional feed to dairy cows. However, studies on feeding peas to dairy cows are very limited, particularly in North America. Contradictory results were reported from Australia (Valentine and Bartsch, 1990) and Canada (Corbett et al., 1995). Milk yield was increased with the inclusion of ground peas replacing barley grain in the former study, whereas partial substitution of barley grain, SBM, and canola meal with peas resulted in decreased milk yield of midlactation cows in the latter study. Another Canadian study (Petit et al., 1997) reported no effect of inclusion of $20 \%$ peas in the diet (replacing corn grain and SBM) on DMI and milk yield and composition. Other reports (Khorasani et al., 2001; Vanhatalo et al., 2004; Masoero et al., 2006) also found no effect of feeding peas on milk production or composition, or the results were influenced by differences in DM and CP intake (Froidmont and BartiauxThill, 2004). The effect of feeding peas on milk organoleptic characteristics has not been studied in dairy cows. Thus, there is a need for more research, particularly in the United States, on the effects of inclusion of field peas in the diets of lactating dairy cows on milk yield and composition, digestibility of dietary nutrients, $\mathrm{N}$ losses, and organoleptic characteristics of milk.

The hypothesis tested in this experiment was that partial substitution of SBM and corn grain with peas 
in the diet of lactating dairy cows will not affect milk yield and composition. Our specific objectives were to investigate the effect of isonitrogenous and isoenergetic substitution of $15 \%$ of dietary DM (as solvent-extracted SBM and steam-rolled corn grain) with field peas in the diet of high-producing Holstein dairy cows on milk yield, composition, and organoleptic characteristics of milk, total tract digestibility, and urinary $\mathrm{N}$ losses.

\section{MATERIALS AND METHODS}

\section{Animals and Feeding}

All procedures involving animals were approved by the University of Idaho Animal Care and Use Committee (Protocol 2005-59). Seventeen multiparous (average parity $3.1, \mathrm{SD}=1.09$ ) and 7 primiparous Holstein cows were blocked based on parity, DIM, and milk yield during a 2-wk covariate period. Average DIM, BW, and milk yield of the cows before initiation of the experiment were $($ mean $\pm \mathrm{SD}): 104 \pm 39.3 \mathrm{~d}, 665 \pm 69.2 \mathrm{~kg}$, and 39 $\pm 5.9 \mathrm{~kg} / \mathrm{d}$, respectively. Cows were fed the control diet (Table 1) during the covariate period and randomly assigned (within block) to the control or pea diets for the remaining of the trial. The 2 diets were fed for 10 wk; the first 2 wk were allowed for adaptation and measurements were taken during the following $8 \mathrm{wk}$. Cows did not receive recombinant bST during the trial.

The diets were formulated (NRC, 2001) to provide similar amounts of $\mathrm{NE}_{\mathrm{L}}, \mathrm{CP}, \mathrm{RDP}$, and RUP and meet or exceed the nutrient requirements (at $25 \mathrm{~kg} / \mathrm{d} \mathrm{DMI}$ ) of a Holstein cow yielding $35 \mathrm{~kg}$ of milk/d with $3.7 \%$ milk fat and $3.0 \%$ true protein. Approximately $45 \%$ of the corn grain and $78 \%$ of the SBM in the control diet were replaced with $15 \%$ (DM basis) field peas in the experimental diet. The peas used in the trial (Colombia Grain, Colfax, WA) were graded US No. 1 feed peas according to the US Standards for Feed Peas and contained $25 \% \mathrm{CP}$ and estimated $1.98 \mathrm{Mcal}$ of $\mathrm{NE}_{\mathrm{L}} / \mathrm{kg}$ (Table 1). The proportions of the other feed ingredients were similar between the 2 diets. Peas were coarsely ground through a hammer mill (New Holland, model 200, New Holland, PA) before feeding. The geometrical mean diameter of the ground peas was $1.44 \mathrm{~mm}$ (sieve shaker AS200, Retsch GmbH, Haan, Germany). Diets were fed as TMR at 0700 and $1700 \mathrm{~h}$. Diets were mixed once daily, before the $0700 \mathrm{~h}$ feeding and were fed ad libitum to about 5 to $10 \%$ orts. Cows had free access to fresh water and salt blocks throughout the duration of the trial.

\section{Sampling and Analyses}

Individual forages, TMR, and orts were sampled daily, and concentrate feeds were sampled weekly.
Table 1. Ingredient and chemical composition of the diets fed in the trial

\begin{tabular}{|c|c|c|}
\hline \multirow[b]{2}{*}{ Ingredient } & \multicolumn{2}{|c|}{ Diet (\%, DM basis) } \\
\hline & Control & Pea \\
\hline Alfalfa hay ${ }^{1}$ & 28.0 & 28.0 \\
\hline Corn silage $^{2}$ & 17.7 & 17.7 \\
\hline Cottonseed, whole with lint & 7.0 & 7.0 \\
\hline Corn grain, steam-rolled & 19.8 & 10.8 \\
\hline Soybean meal, solvent, $48 \% \mathrm{CP}$ & 7.4 & 1.6 \\
\hline Peas $^{3}$ & - & 15.0 \\
\hline Dry distiller grain with solubles & 6.0 & 6.0 \\
\hline Barley grain, steam-rolled & 12.0 & 11.8 \\
\hline Mineral/vitamin mix $^{4}$ & 2.1 & 2.1 \\
\hline \multicolumn{3}{|l|}{ Composition $^{5}$} \\
\hline $\mathrm{CP}$ & 15.7 & 15.5 \\
\hline $\mathrm{RDP}, \%$ of $\mathrm{CP}$ & 67.1 & 67.7 \\
\hline RUP, $\%$ of CP & 32.9 & 32.3 \\
\hline $\mathrm{NE}_{\mathrm{L}}, \mathrm{Mcal} / \mathrm{kg} \mathrm{DM}$ & 1.56 & 1.55 \\
\hline $\mathrm{NDF}$ & 35.0 & 38.2 \\
\hline Starch & 18.8 & 15.8 \\
\hline NFC & 42.7 & 43.5 \\
\hline
\end{tabular}

${ }^{1}$ Alfalfa hay was $84 \% \mathrm{DM}$ and (DM basis): $18.5 \% \mathrm{CP}$, and $43.4 \%$ NDF.

${ }^{2}$ Corn silage was $30 \% \mathrm{DM}$ and (DM basis): $6.0 \% \mathrm{CP}$, and $48.2 \%$ NDF.

${ }^{3}$ Peas were US No. 1 Feed peas (Federal Grain Inspection Service, Moscow, ID) and contained 11\% moisture and (DM basis): CP, 25.3\% (83\% soluble); starch, 48.0\%; NDF, 9.2\%; ADF, 5.1\%; lignin, 0.3\%; fat, $1.0 \%$; ash, $2.1 \%$; Ca, $0.08 \% ; \mathrm{P}, 0.41 \% ; \mathrm{Mg}, 0.12 \% ; \mathrm{K}, 0.92 \% ; \mathrm{Na}$, $0.002 \%$; S, 0.18\%; Fe, $63 \mathrm{mg} / \mathrm{kg}$; Zn, $43 \mathrm{mg} / \mathrm{kg} ; \mathrm{Cu}, 9 \mathrm{mg} / \mathrm{kg} ; \mathrm{Mn}, 11$ $\mathrm{mg} / \mathrm{kg}$ and estimated $\mathrm{NE}_{\mathrm{L}}, 1.98 \mathrm{Mcal} / \mathrm{kg}$; TDN 86\%; and NFC, $67 \%$ (DairyOne, Ithaca, NY). Lysine and methionine concentrations were 6.48 and $0.88 \%$ of CP, respectively (Michigan State University, East Lansing).

${ }^{4}$ Mineral-vitamin premix (Land O'Lakes, Saint Paul, MN) composition (as-is basis): Ca, $15.8 \% ; \mathrm{P}, 4.7 \% ; \mathrm{Mg}, 5.2 \% ; \mathrm{Cl}, 2.8 \% ; \mathrm{K}, 0.3 \%$; $\mathrm{Na}, 6.5 \%$; S, 0.3\%; Co, $4.36 \mathrm{mg} / \mathrm{kg}$; Cu, $928 \mathrm{mg} / \mathrm{kg} ; \mathrm{I}, 42 \mathrm{mg} / \mathrm{kg} ; \mathrm{Fe}$, $189 \mathrm{mg} / \mathrm{kg} ; \mathrm{Mn}, 4.7 \mathrm{mg} / \mathrm{kg} ; \mathrm{Se}, 15.7 \mathrm{mg} / \mathrm{kg} ; \mathrm{Zn}, 4,649 \mathrm{mg} / \mathrm{kg}$; vitamin A, 258,000 IU/kg; vitamin D, 45,900 IU/kg; and vitamin E, 1,839 IU/ $\mathrm{kg}$.

${ }^{5} \mathrm{RDP}, \mathrm{RUP}, \mathrm{NE}_{\mathrm{L}}$, and NFC were estimated by NRC (2001); CP, starch, and forage composition were analyzed by Cumberland Valley Analytical Services Inc. (Maugansville, MD).

Samples were composited and analyzed for DM $\left(65^{\circ} \mathrm{C}\right.$ in a forced-air oven, dried to a constant weight) and ash/OM, N, NDF, and starch by Cumberland Valley Analytical Services, Inc. (Maugansville, MD). Composite TMR samples were analyzed for acid-insoluble ash (AIA; Van Keulen and Young, 1977).

Fecal grab samples (approximately $400 \mathrm{~g} / \mathrm{sample}$ ) were collected from each cow from the ground when fresh or from the rectum 3 times at 12-h intervals over the course of $2 \mathrm{~d}$ at the end of the covariate period and experimental wk 3,6, and 9. Fecal samples were dried at $65^{\circ} \mathrm{C}$ in a forced-air oven to constant weight, ground through a 1-mm sieve, and composited per animal and period on a DM basis. Composite samples were analyzed for ash/OM, N, NDF, and starch as indicated earlier, and AIA. Apparent total tract digestibility was 
estimated using AIA as an intrinsic digestibility marker (Foley et al., 2006).

Spot urine samples (approximately $300 \mathrm{~mL} / \mathrm{sample}$ ) were collected by massaging the vulva at the same times as the fecal samples were collected. Urine samples were acidified to a $\mathrm{pH}<3.0$ by addition of $2 M$ $\mathrm{H}_{2} \mathrm{SO}_{4}$ and aliquots were diluted with distilled water. Diluted samples were then frozen at $-20^{\circ} \mathrm{C}$ and later analyzed (1:20 dilution) for creatinine and urea (Broderick et al., 2007), allantoin (Foley et al., 2006), and uric acid (commercial kit; Teco Diagnostics, Anaheim, CA) and N (1:10 dilution; Foley et al., 2006).

Daily milk yields were recorded during the entire experiment. Milk samples were collected from the milking parlor twice daily on the last day of the covariate period and during wk $2,4,6,8$, and 10 of the experimental period. Milk samples were analyzed for fat, true protein, lactose, SNF, and MUN (Rocky Mountain DHIA, Logan, Utah).

In wk 6 of the experimental period, a composite milk sample $(36 \mathrm{~kg})$ from each treatment was collected into stainless steel milk cans, pasteurized, and assessed for organoleptic characteristics by a trained consumer panel at Washington State University (Pullman, WA). Raw milk was pasteurized at $72^{\circ} \mathrm{C}$ for $30 \mathrm{~s}$ using a continuous plate heat exchanger (Processing Machinery \& Supply Co., Philadelphia, PA). Forty untrained panelists evaluated 4 milk samples per treatment in private booths using Compusense Five software (release 4.6, Guelph, Canada). A balanced reference duotrio test was used to determine the consumers' ability to distinguish differences between control samples. Panelists were then served 2 sets of samples in which the reference was either milk from the control diet or pea diet cows. In every set, one sample was identical to the reference and one was different. After being presented with a sample set, panelists were asked to identify the sample that tasted the same as the reference. Control and treatment serving was randomized, and samples were blind-coded using random 3-digit code numbers.

\section{Statistical Analysis}

Nutrient intake (except DMI), digestibility, and urine data were analyzed using analysis of covariance and the MIXED procedure of SAS (2003; SAS Inst., Inc., Cary, NC). The model used was

$$
\mathrm{Y}_{\mathrm{ijk}}=\mu+\beta_{\mathrm{i}}+\tau_{\mathrm{j}}+\beta \tau_{\mathrm{ij}}+\mathrm{c}_{\mathrm{K}}+\mathrm{e}_{\mathrm{ijk}}
$$

where $\mu$ is the overall mean, $\beta_{\mathrm{i}}$ is the block effect, $\tau_{\mathrm{j}}$ is the treatment effect, $\beta \tau_{\mathrm{ij}}$ is the block $\times$ treatment interaction, $c_{K}$ is the covariate, with the error term $e_{i j k}$ assumed to be normally distributed with mean $=0$ and constant variance. Blocks and block $\times$ treatment interaction were random effects, whereas all others were fixed.

Dry matter intake and milk production and composition data were analyzed as repeated measures. The model used was

$$
\mathrm{Y}_{\mathrm{ijkl}}=\mu+\beta_{\mathrm{i}}+\tau_{\mathrm{j}}+\beta \tau_{\mathrm{ij}}+\mathbf{c}_{\mathrm{k}}+\mathrm{D}_{\mathrm{l}}+\tau \mathrm{D}_{\mathrm{jl}}+\mathrm{e}_{\mathrm{ijk} \mathrm{k}},
$$

where $\mu$ is the overall mean, $\beta_{\mathrm{i}}$ is the block effect, $\tau_{\mathrm{j}}$ is the treatment effect, $\beta \tau_{\mathrm{ij}}$ is the block $\times$ treatment interaction, $c_{K}$ is the covariate, $D_{1}$ is the time effect, $\tau D_{j 1}$ is the treatment $\times$ time interaction, with the error term $\mathrm{e}_{\mathrm{ijk}}$ assumed to be normally distributed with mean $=0$ and constant variance. Blocks and block $\times$ treatment interaction were random effects, whereas all others were fixed.

Statistical difference was declared at $P \leq 0.05$. Milk organoleptic characteristics data were analyzed using ANOVA.

\section{RESULTS AND DISCUSSION}

The 2 diets had similar concentrations of CP, RDP, RUP, $\mathrm{NE}_{\mathrm{L}}$, and NFC, but the pea diet had slightly greater NDF and lower starch content (Table 1), which reflects the difference in starch content between corn grain and peas. The diets were originally formulated to contain $18 \% \mathrm{CP}$, but the source of the alfalfa hay changed immediately before the initiation of the trial and the diets fed during the trial had significantly lower $\mathrm{CP}$ content than initially targeted. The peas used in this trial contained $25.3 \% \mathrm{CP}$ and $48.0 \%$ starch. Pea cultivars may vary significantly in their composition, particularly protein and starch (Reichert and MacKenzie, 1982; Wang and Daun, 2004; Tzitzikas et al., 2006). Peas contain high proportions of lysine $(7.4 \%)$ and arginine in their protein and have relatively low proportions of methionine, cystine, and tryptophan (Lalles, 1993). On a CP basis, the lysine and methionine content of the peas used in the current trial was 6.48 and $0.88 \%$, respectively (see Table 1 footnote). Thus, the pea diet provided slightly more lysine (6.43 vs. $6.27 \%$ ) and less methionine (1.78 vs. $1.89 \%$ ), as a proportion of MP, compared the control diet (NRC, 2001). Apparently, both diets in this trial supplied less lysine and methionine than recommended by NRC (2001). If peas are replacing feeds with higher methionine contents (such as corn grain and SBM) in the diets of high-producing dairy cows, provision of additional methionine may be necessary.

Dry matter intake and milk yield were not different $(P=0.67$ and 0.79 , respectively) between the 2 diets 
Table 2. Effect of inclusion of field peas in the diet on DMI, milk yield and composition, and BW change in lactating dairy cows (least squares means; $\mathrm{n}=1,608$, DMI and milk yield; $\mathrm{n}=120$, milk composition)

\begin{tabular}{|c|c|c|c|c|}
\hline \multirow[b]{2}{*}{ Item } & \multicolumn{2}{|c|}{ Diet } & \multirow[b]{2}{*}{ SE } & \multirow[b]{2}{*}{$P={ }^{1}$} \\
\hline & Control & Pea & & \\
\hline DMI, kg/d & 25.9 & 26.3 & 0.67 & 0.67 \\
\hline Milk yield, $\mathrm{kg} / \mathrm{d}$ & 35.4 & 35.6 & 0.85 & 0.79 \\
\hline $4 \% \mathrm{FCM}, \mathrm{kg} / \mathrm{d}$ & 33.0 & 34.6 & 1.38 & 0.41 \\
\hline Milk yield/DMI & 1.47 & 1.38 & 0.044 & 0.18 \\
\hline Milk fat, $\%$ & 3.54 & 3.76 & 0.124 & 0.15 \\
\hline Milk fat, kg/d & 1.25 & 1.27 & 0.058 & 0.81 \\
\hline Milk true protein, $\%$ & 3.00 & 2.99 & 0.046 & 0.85 \\
\hline Milk true protein, $\mathrm{kg} / \mathrm{d}$ & 1.05 & 1.02 & 0.039 & 0.53 \\
\hline Milk lactose, $\%$ & 4.84 & 4.86 & 0.026 & 0.43 \\
\hline Milk lactose, kg/d & 1.67 & 1.72 & 0.064 & 0.56 \\
\hline Milk SNF, \% & 8.76 & 8.79 & 0.050 & 0.63 \\
\hline Milk SNF, kg/d & 4.01 & 3.96 & 0.044 & 0.37 \\
\hline MUN, mg/dL & 14.3 & 15.0 & 0.35 & 0.24 \\
\hline $\mathrm{BW}$ gain, $\mathrm{kg} / \mathrm{d}$ & 0.47 & 0.40 & 0.103 & 0.58 \\
\hline
\end{tabular}

${ }^{1}$ Main effect of diet.

(Table 2). Fat-corrected milk yield and concentration and yield of milk components were also not affected $(P=0.15$ to 0.85 , respectively) by inclusion of $15 \%$ peas in the diet. Milk fat percentage was numerically greater (by $6 \% ; P=0.15$ ) with the pea diet compared with the control diet. Milk urea $\mathrm{N}$ levels were also not different $(P=0.24)$ between the diets. Cows on both diets gained similar BW $(P=0.58)$ during the trial.

Data on the effect of field peas on productivity of dairy cows are scarce. An Australian study with relatively low-producing dairy cows (milk yield of 18 to 20 $\mathrm{kg} / \mathrm{d}$ ) reported a $0.9 \mathrm{~kg} / \mathrm{d}$ increase in milk yield with the inclusion of $3.5 \mathrm{~kg} / \mathrm{d}$ of ground peas replacing barley grain (Valentine and Bartsch, 1990). Milk fat content was not affected by the treatments, but milk protein concentration and yield were increased by the pea compared with the control, barley diet. The basal diet in the Australian study had rather low CP content (8 to 9\%) and the response to inclusion of peas (as well as other leguminous seeds) was apparently due to an increase in dietary protein supply. A Canadian study with dairy cows producing around $30 \mathrm{~kg}$ of milk/d, reported that isonitrogenous and isoenergetic substitution of barley grain, SBM, and canola meal with field peas (in a pelleted supplement) resulted in decreased milk yield (by 10\%) of midlactation cows (Corbett et al., 1995). Milk production of the same cows in early and late lactation was not affected by the substitution. The authors reported increased milk fat percentage with the pea diet in early lactation cows; thus, FCM was not different between the 2 diets. Similar to the present experiment, Petit et al. (1997) replaced $20 \%$ of dietary DM (as corn grain and SBM) with ground or extruded peas and reported no effect of diet on DMI and milk
Table 3. Effect of inclusion of field peas in the diet on intake and apparent total tract digestibility of nutrients in lactating dairy cows (least squares means; $\mathrm{n}=24$ )

\begin{tabular}{|c|c|c|c|c|}
\hline \multirow[b]{2}{*}{ Item } & \multicolumn{2}{|c|}{ Diet } & \multirow[b]{2}{*}{ SE } & \multirow[b]{2}{*}{$P={ }^{1}$} \\
\hline & Control & Pea & & \\
\hline \multicolumn{5}{|c|}{ Intake, $\mathrm{kg} / \mathrm{d}$} \\
\hline $\mathrm{OM}$ & 23.5 & 24.3 & 0.65 & 0.43 \\
\hline $\mathrm{N}$ & 0.642 & 0.656 & 0.0179 & 0.58 \\
\hline NDF & 9.0 & 10.1 & 0.26 & 0.01 \\
\hline Starch & 4.8 & 4.2 & 0.13 & 0.004 \\
\hline \multicolumn{5}{|c|}{ Apparent digestibility, \% } \\
\hline $\mathrm{DM}$ & 74.5 & 72.5 & 0.97 & 0.07 \\
\hline $\mathrm{OM}$ & 76.0 & 74.0 & 1.00 & 0.07 \\
\hline $\mathrm{N}$ & 73.6 & 72.7 & 0.87 & 0.48 \\
\hline NDF & 61.4 & 61.1 & 1.46 & 0.88 \\
\hline Starch & 92.1 & 88.3 & 0.82 & 0.004 \\
\hline
\end{tabular}

${ }^{1}$ Main effect of diet.

yield and composition. Milk urea $\mathrm{N}$ concentration appeared to be increased by the pea diets, as was BUN. In another Canadian study, an increased proportion of peas in the diet (from 10 to 30\%, replacing SBM and barley grain) did not affect milk yield and composition, except that there was a quadratic increase in milk protein concentration compared with the control diet (Khorasani et al., 2001). Compared with SBM, inclusion of $14 \%$ peas (DM basis) in the diet decreased milk yield and concentration of MUN in Holstein dairy cows producing $36 \mathrm{~kg}$ of milk/d, but these results were apparently influenced by reduced DM and CP intake with the pea diet (Froidmont and Bartiaux-Thill, 2004). Masoero et al. (2006) substituted unprocessed or extruded peas for SBM at $12 \%$ of dietary DM and found no differences in DMI and milk yield and composition among diets. Replacing a portion of a barley-based concentrate with dry or ensiled peas in the diet of Finnish Ayrshire cows produced no effect in milk yield and composition (Vanhatalo et al., 2004). Overall, published reports and data from this experiment suggest that inclusion of 15 to $20 \%$ peas in dairy cow diets does not have a significant impact on milk yield and composition.

Intake of $\mathrm{OM}$ and $\mathrm{N}$ was not different $(P=0.43$ and 0.58 , respectively) between the 2 diets (Table 3 ). Intake of NDF was lower $(P=0.01)$ and that of starch was greater $(P=0.004)$ for the control compared with the pea diet. Total tract apparent digestibility of $\mathrm{N}$ and NDF were not affected ( $P=0.48$ and 0.88 , respectively) by diet, but digestibility of starch was lower $(P=0.004)$ with the pea diet compared with the control. Digestibility of DM and OM also tended to be lower $(P=0.07)$ with the pea diet. Because digestibility of NDF and $\mathrm{N}$ were similar between the diets, it was the lower digestibility of dietary starch that caused the numerical decrease in DM digestibility of the pea diet. The greater 
Table 4. Effect of inclusion of field peas in the diet on $\mathrm{N}$ utilization in lactating dairy cows (least squares means; $\mathrm{n}=24$ )

\begin{tabular}{|c|c|c|c|c|}
\hline \multirow[b]{2}{*}{ Item } & \multicolumn{2}{|c|}{ Diet } & \multirow[b]{2}{*}{$\mathrm{SE}$} & \multirow[b]{2}{*}{$P={ }^{1}$} \\
\hline & Control & Pea & & \\
\hline $\mathrm{N}$ intake, $\mathrm{g} / \mathrm{d}$ & 642 & 656 & 17.9 & 0.58 \\
\hline Milk protein $\mathrm{N},{ }^{2} \mathrm{~g} / \mathrm{d}$ & 166 & 160 & 5.6 & 0.40 \\
\hline Milk protein N/N intake & 0.26 & 0.24 & 0.009 & 0.23 \\
\hline Fecal N, g/d & 172 & 180 & 6.7 & 0.33 \\
\hline Fecal N/N intake & 0.26 & 0.27 & 0.009 & 0.48 \\
\hline Urinary $\mathrm{N}, \mathrm{g} / \mathrm{d}$ & 238 & 256 & 10.9 & 0.19 \\
\hline Urinary N/N intake & 0.37 & 0.39 & 0.017 & 0.39 \\
\hline Urea $\mathrm{N}, \mathrm{g} / \mathrm{d}$ & 151 & 151 & 5.26 & 0.92 \\
\hline Proportion of total $\mathrm{N}$ & 0.64 & 0.60 & 0.020 & 0.22 \\
\hline Proportion of $\mathrm{N}$ intake & 0.24 & 0.23 & 0.008 & 0.76 \\
\hline Allantoin, $\mathrm{mmol} / \mathrm{d}$ & 443 & 468 & 26.3 & 0.41 \\
\hline Uric acid, $\mathrm{mmol} / \mathrm{d}$ & 63 & 66 & 5.9 & 0.69 \\
\hline Allantoin and uric acid, $\mathrm{mmol} / \mathrm{d}$ & 508 & 533 & 29.6 & 0.45 \\
\hline
\end{tabular}

starch intake with the control diet did not have an effect on fiber digestibility.

In the study by Petit et al. (1997), apparent total tract digestibility of $\mathrm{DM}$ and $\mathrm{N}$ was greater for the extruded peas and appeared to be increased for the ground pea diet compared with the control. Digestibility of dietary fiber was similar among the diets. Khorasani et al. (2001) reported a quadratic reduction in apparent total tract digestibility of fiber (NDF and $\mathrm{ADF}$ ) with an increasing proportion of peas in the diet. Compared with SBM, inclusion of $14 \%$ peas (dietary DM basis) resulted in decreased $\mathrm{N}$ digestibility but increased crude fiber digestibility in the study of Froidmont and Bartiaux-Thill (2004). In contrast to results from the present experiment, Vanhatalo et al. (2004) reported increased ruminal and total tract apparent digestibility of OM when peas replaced a portion of a barley-based concentrate in the diet of Finnish Ayrshire cows. In beef cattle, increased supplementation of field peas to a grass hay diet linearly increased apparent total tract digestibility of dietary $\mathrm{N}$, but had no effect on ruminal or total tract OM digestibility (Reed et al., 2004). In summary, the effect of peas on dietary nutrient digestibility is inconsistent. Composition of the basal diet, inclusion rate, level of intake and production, and pea cultivar (which is rarely reported) are most likely among the factors responsible for this variable effect.

The efficiency of utilization of dietary $\mathrm{N}$ for milk protein synthesis was similar $(P=0.23)$ between the 2 diets (Table 4). Excretion of $\mathrm{N}$ with feces and urine were also not different ( $P=0.33$ and 0.19 , respectively) between the control and pea diets. Overall excretion of urinary urea and as a proportion of $\mathrm{N}$ intake were not affected ( $P=0.92$ and 0.76 , respectively) by the inclusion of peas in the diet. In contrast to these results,
Petit et al. (1997) reported increased urinary N losses when peas (ground or extruded) replaced $20 \%$ of dietary DM. Excretion of allantoin and uric acid, as indicators of ruminal synthesis and postruminal absorption of microbial protein, was similar $(P=0.41$ to 0.69$)$ between the 2 diets, which suggests similar outflow of microbial protein from the rumen.

Panel evaluation of milk from the 2 diets indicated no differences in the organoleptic characteristics of milk $(P=0.71)$. Regardless of whether the experimental or the control sample was presented as the reference, panelists guessed right or wrong about 50\% of the time; 19 correct answers and 21 wrong answers for both orders of presentation. Thus, the inclusion of peas in the diet did not appear to affect the organoleptic characteristics of milk. To our knowledge, this is the first report on the effect of peas on organoleptic characteristics of bovine milk. An extension publication from Tulare County, California, suggested that green peas cause little or no feed flavor in goat milk (TriCounty Goat Newsletter; University of California Cooperative Extension; available from http://www.saanendoah.com/milkqf.html). Legume seeds are rich in plant secondary metabolites (Troszynska et al., 1997; Shahidi et al., 2001; Duenãs et al., 2004), which are known to influence the taste and preservation of food and to improve human health (Poulet et al., 2002). The seed coat and the cotyledon of peas contain high concentrations of flavonoid (quercetin, luteolin, and apigenin) and nonflavonoid (hydroxybenzoic and hydroxycinnamic acids) phenolic compounds (Duenãs et al., 2004). These compounds have strong antioxidant activities, may contribute to milk flavor, and are characterized as health-promoting and cancer-preventive agents (Besle et al., 2005; Duenãs et al., 2006; Moon et al., 2006). The diet can have a powerful effect on milk composition. In the study by Besle et al. (2005), concentration of phenolic compounds in milk varied from 4.0 to $10.8 \mathrm{mg} / \mathrm{L}$ depending on the amount of concentrate and the type of forage in the diet of dairy cows. Phenolic compounds were not analyzed in milk samples from this experiment, but future investigation of the effect of peas and other leguminous seeds on milk phenolic, particularly flavonoid, concentration may be warranted.

\section{CONCLUSIONS}

This experiment demonstrated that ground field peas could be safely fed to high-producing dairy cows at a $15 \%$ inclusion rate, replacing SBM and corn grain. At this substitution rate, no effects on DMI, milk yield, or milk composition were observed. Concentration of methionine in pea protein is lower than in SBM and cereal grains and provision of supplemental methionine 
may be necessary when peas are fed to high-producing dairy cows. Total tract apparent digestibility of starch was decreased with the pea diet, which resulted in a slight decrease in dietary DM and OM digestibility, compared with the control diet. Urinary and fecal $\mathrm{N}$ losses were not affected by diet. Panel evaluation of milk from the experimental cows indicated no differences in the organoleptic characteristics of milk between the 2 diets.

\section{ACKNOWLEDGMENTS}

This study was partially supported by funds from the Cool Season Food Legumes Program Special Research Grant (USDA-CSREES) and the Idaho Agricultural Experiment Station. The authors would like to thank the staff of the Department of Animal and Veterinary Science Dairy Center for their conscientious care of the experimental cows and W. Price for assistance with statistical evaluation of the results.

\section{REFERENCES}

Besle, J. M., J. L. Lamaison, B. Dujol, P. Pradel, D. Fraisse, D. Viala, and B. Martin. 2005. Flavonoids and other phenolics in milk as a putative tool for traceability of dairy production systems. Pages 345-350 in Indicators of Milk and Beef Quality. J. F. Hocquette and S. Gigli, ed. INRA, Clermont Ferrand-Theix, France.

Beyer, M., A. Chudy, L. Hoffmann, W. Jentsch, W. Laube, K. Nehring, and R. Schiemann. 2003. Rostock Feed Evaluation System. Plexus Verlag, Miltenberg-Frankfurt, Germany.

Broderick, G. A., A. F. Brito, and J. J. Olmos Colmenero. 2007. Effects of feeding formate-treated alfalfa silage or red clover silage on the production of lactating dairy cows. J. Dairy Sci. 90:1378-1391.

Corbett, R. R., E. K. Okine, and L. A. Goonewardene. 1995. Effects of feeding peas to high-producing dairy cows. Can. J. Anim. Sci. 75:625-629.

Duenãs, M., T. Hernandez, and I. Estrella. 2004. Occurrence of phenolic compounds in the seed coat and the cotyledon of peas (Pisum sativum L.). Eur. Food Res. Technol. 219:116-123.

Duenãs, M., T. Hernandez, and I. Estrella. 2006. Assessment of in vitro antioxidant capacity of the seed coat and the cotyledon of legumes in relation to their phenolic contents. Food Chem. 98:95-103.

Foley, A. E., A. N. Hristov, A. Melgar, J. K. Ropp, R. P. Etter, S. Zaman, C. W. Hunt, K. Huber, and W. J. Price. 2006. Effect of barley and its amylopectin content on ruminal fermentation and nitrogen utilization in lactating dairy cows. J. Dairy Sci. 89:4321-4335.
Froidmont, E., and N. Bartiaux-Thill. 2004. Suitability of lupin and pea seeds as a substitute for soybean meal in high-producing dairy cow feed. Anim. Res. 53:475-487.

Khorasani, G. R., E. K. Okine, R. R. Corbett, and J. J. Kennelly. 2001. Nutritive value of peas for lactating dairy cattle. Can. J. Anim. Sci. 81:541-551.

Lalles, J. P. 1993. Nutritional and antinutritional aspects of soyabean and field pea proteins used in veal calf production: A review. Livest. Prod. Sci. 34:181-202.

Masoero, F., M. Moschini, G. Fusconi, and G. Piva. 2006. Raw, extruded and expanded pea (Pisum sativum) in dairy cow diets. Ital. J. Anim. Sci. 5:237-247.

Moon, Y. J., X. D. Wang, and M. E. Morris. 2006. Dietary flavonoids: Effects on xenobiotic and carcinogen metabolism. Toxicol. In Vitro 20:187-210.

NRC. 1998. Nutrient Requirements of Swine. 10th rev.ed. National Academy Press, Washington, DC.

NRC. 2001. Nutrient Requirements of Dairy Cattle. 7th rev.ed. National Academy Press, Washington, DC.

Petit, H. V., R. Rioux, and D. R. Ouellet. 1997. Milk production and intake of lactating cows fed raw or extruded peas. J. Dairy Sci. 80:3377-3385.

Poulet, J. L., D. Fraisse, D. Viala, A. Carnat, P. Pradel, B. Martin, J. L. Lamaison, and J. M. Besle. 2002. Flavonoids in forages: Composition and possible effects on milk quality. Pages 590-591 in Multi-functional Grasslands: Quality Forages, Animal Products and Landscapes. J. L. Durand, J. C. Emile, C. Huyghe, and G. Lemaire, ed. Proc. 19th General Mtg. Eur. Grassl. Fed., La Rochelle, France. INRA, Clermont Ferrand-Theix, France.

Reed, J. J., G. P. Largy, M. L. Bauer, T. C. Gilbery, and J. S. Caton. 2004. Effect of field pea level on intake, digestion, microbial efficiency, ruminal fermentation, and in situ disappearance in beef steers fed forage-based diets. J. Anim. Sci. 82:2185-2192.

Reichert, R., and S. L. MacKenzie. 1982. Composition of peas varying widely in protein content. J. Agric. Food Chem. 30:312-317.

Shahidi, F., U. D. Chavan, M. Naczk, and R. Amarowicz. 2001. Nutrient distribution and phenolic antioxidants in air-classified fractions of beach pea (Lathyrus maritimus L.). J. Agric. Food Chem. 49:926-933.

Troszynska, A., A. Bednarska, A. Latosz, and H. Kozlowska. 1997. Polyphenolic compounds in the seed coat of legume seeds. Polish J. Food Nutr. Sci. 6:37-45.

Tzitzikas, E. N., J.-P. Vincken, J. De Groot, H. Gruppen, and R. G. F. Visser. 2006. Genetic variation in pea seed globulin composition. J. Agric. Food Chem. 54:425-433.

Valentine, S. C., and B. D. Bartsch. 1990. Milk production by dairy cows fed legume grains or barley grain with or without urea as supplements to a cereal hay based diet. Aust. J. Exp. Agric. 30:7-10.

Van Keulen, J., and B. A. Young. 1977. Evaluation of acid-insoluble ash as a natural marker in ruminant digestibility studies. J. Anim. Sci. 44:282-287.

Vanhatalo, A., S. Ahvenjärvi, and S. Jaakkola. 2004. Metabolic and production responses in dairy cows fed peas or rapeseed meal on grass silage based diets. J. Anim. Feed Sci. 13(Suppl. 1):231-234.

Wang, N., and J. K. Daun. 2004. Effect of variety and crude protein content on nutrients and certain antinutrients in field peas $(P i$ sum sativum). J. Sci. Food Agric. 84:1021-1029. 